\title{
Obituaries
}

Obituaries should be submitted by email to Kate Maynard at k.maynard@nature.com.

All submitted obituaries should be 350 words maximum in length (apart from obituaries fo past presidents of the BDA

where the length should be 700-800 words)

Content of the obituary is down to the individual author, and the approval of the family should be given for the obituary prior

to submission to the $B D J$.

\section{JOSEPHINE MARY PRIOR}

On a beautiful day in June, Gloucester cathedral was filled with those who had come to bid farewell to Jo Prior (Josie Greenwood) and to sympathise with her husband John over his loss.

The four of her contemporaries from student days heard in the eulogy of a life packed with achievement, which made one of the readings, from Tennyson's Ulysses, particularly apt:

I am a part of all that I have met / Yet all experience is an arch wherethro' / Gleams that untravell'd world whose margin fades / For ever and for ever when I move.

Born in 1942, Josie's family home was in Stamford, Lincolnshire, and she showed early on that she was an achiever by starting her dental course at Guy's Hospital Dental School from an arts background.

Qualifying in 1968, she met John when they were both in Cambridge (she in the school service), and they married in 1972. Moving to London, they lived first in Islington, and then South London, conveniently close to New Cross, where she taught the Dental Auxiliaries (therapists) as Senior Lecturer. Jo continued with her professional advancement, gaining a DDPH RCS(Eng) in 1980.

In 1986 Jo and John moved to Gloucester, and that same year Jo joined the Dental Auxiliary School at Cardiff University as Assistant Director. The School expanded in the early 1990s, and by then as Director Jo was instrumental in setting up the Diploma in Dental Therapy course.

Many at the cathedral knew Jo through her connection with its music, and in her role as Cathedral Guide and Assessor. One of her very last acts, when gravely ill, was to go to St Paul's Cathedral in London to hear her friend David Briggs, Organist Emeritus at Gloucester Cathedral, improvise to accompany the showing of the film King of Kings.

The music at the service did full honour to Jo, the choir singing two anthems, the organ filling the marvellous acoustic of the building with triumphant sound, and the singing of the congregation reflecting just as much joy for a life well lived as sadness for a loss.

JP, MT, PM, RW, DH, CH, MB

\section{ALAN JOHN LAWRENCE OBE}

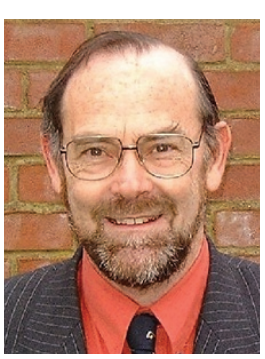

On 3 September 2009 Alan died, aged 68, after a courageous battle against rectal cancer. Friends and colleagues packed the funeral and thanksgiving serv-

ices and many were moved to give tribute to Alan's many acts of kindness and encouragement. Alan's Christian faith was central to his personality and he provided his own moving message to mourners on the service sheet: 'I am dying, but have had a wonderful life and have got a wonderful Saviour.'

At Bristol University he met fellow dental student, Judith and they married in 1963, graduating the following year. They went to Kenya in 1965 and Alan practised as a missionary dental surgeon for four years. He maintained his missionary zeal till the end and was a trustee of Bridge2Aid and Life VicePresident and Trustee of the Christian Dental Fellowship.
On his return from East Africa in 1970, Alan focused on administrative posts; first as CDO in Eastbourne, then moving to Barnet as ADO and finally to Berkshire in 1979 where he remained consultant in dental public health until his retirement in 1998.

He was a most successful founding editor of the journal Evidence-Based Dentistry, a popular postgraduate lecturer and adviser to the Oxford Deanery for 13 years and until 2006 a most effective Retraining and Returning Adviser for UK dentists overseas.

Alan was greatly-respected for his well-informed views and was a valuable member of SDAC. His commitment to any organisation of which he was a member was total and he was an energetic secretary and distinguished president of BASCD. His election as a life member of the BDA in 1998 and the receipt of the civil honour, OBE in 1999 gave him great pleasure.

Alan was an enthusiast and the first to embrace new technology or gadgets in any field. His computer skills were legendary and he generously would share his knowledge with anyone willing to learn. Alan was as proud of his family as they were of him. Our sympathy goes to Judith, son and daughter John and Mary and grandchildren who can be reassured that friends, colleagues and patients will be forever enriched for knowing Alan Lawrence.

Dame Margaret Seward 